\title{
Aspects of Korea-Japan Cultural Exchanges Analyzed Through Tongshinsa Delegations during the National Seclusion Period
}

\author{
By Kyoung-Jin Hur* \\ Young-Sim Cho ${ }^{\dagger}$
}

\begin{abstract}
During the 17th-19th century, both the Joseon and the Edo Shogunate reinforced a National Seclusion Policy. Because direct contact with other nations was rare for these two countries, Joseon's dispatching of the diplomatic Tongshinsa delegation to Edo was an important event. The highest ranking officials of the Tongshinsa delegation exchanged national and royal correspondences, celebrated an ascendancy of a new Shogun, and participated in cultural exchange with their Japanese counterparts. Because the highest ranking officials, the Samsa, were both diplomats and highly knowledgeable scholars, they directly participated in such cultural exchanges. Consequently, they can be said to have led the cultural exchanges in various fields. KoreanJapanese diplomacy in the 17th-19th century greatly reflects the politics, culture, and literature of the two respective countries at that time. This manuscript is dedicated to identifying the various aspects, of the pre-modern era, which are much different from the diplomatic exchanges of today.
\end{abstract}

\section{Introduction}

Korea and Japan are geographically close to one another in northeast Asia. Although they have had multiple diplomatic exchanges in the past, after the Japanese invasion of Korea in the $16^{\text {th }}$ century, these diplomatic policies started to change. At that time Korea was known as Joseon, and aside from Busan, a port city that was close to Japan, Joseon restricted Japanese activity into its territory. Nevertheless, Joseon sent special ambassadors, known as "Tongshinsa", all the way to Edo to deliver national messages and congratulate a shogun's ascendance.

The act of sending a diplomatic Tongshinsa delegation was resumed after 1607 , and continued on for approximately 200 years until the $12^{\text {th }}$ and last delegation to Tsushima in 1811. A Tongshinsa delegation numbered from 300 to 500 people, and consequently, the host country Japan's expenses were large. Because Japan gained little compared to the cost of hosting a Tongshinsa delegation, the number of diplomatic visits started to decrease.

Premodern East Asian used Chinese Characters as a common method of communication. Although interpreters capable of spoken communication

\footnotetext{
* Professor, Yonsei University, South Korea.

$\dagger \mathrm{PhD}$ Student, Yonsei University, South Korea.
} 
existed, a large number was never needed as a Korea-Japan exchange happened only once every 20 years during the $17^{\text {th }}$ to $19^{\text {th }}$ century time period. As a result, interpretation was only needed during formal diplomatic occasions. During such exchanges, the ambassadors from both countries communicated with written language, and these records can be seen even today in Sahangrok (使行錄[Record of a Diplomatic Envoy]) and Pildamchanghwaejib (筆談唱和集[Record of written conversations and poetry]).

A Sahangrok is a personal record of a Korean ambassador's experience in Japan, and thus can be classified as a personal travel essay. Because a Sahangrok is usually written after a diplomatic sojourn, most Sahangroks remain in Korea. On the other hand, a Pildamchanghwaejib is a record of poetry and written conversations between the two countries, and it was published by the Japanese whenever it was recorded. Consequently, most Pildamchangjwaejibs are in Japan.

Until now, two of our researchers, Hur kyoung-jin and Cho Young-sim, have gathered and analyzed 47 Sahangroks and 167 Pildamchanghwaejibs. The large number of Pildamchanghwaejibs suggests that there were many occurrences of written communication, in the form of prose and poetry, between Korea and Japan. A special detail to note is the participation of the three highest ranking diplomats, the Samsa (which were called the Jeongsa(正使), the Busa(副使), and the Jongsagwan(從事官)), in these poetry and prose exchanges. These high ranking officials composed their own poetry and sometimes even drew their thoughts, even though there were occupations such the Moonsa (文士), the official in charge of written communications, and Hwasa (畫師), the official in charge of drawn communication.

The nature of the diplomatic exchanges reflected the relationship between the two countries at that time. The period after the Japanese Invasion of Korea in the $16^{\text {th }}$ century was a period of tension, and Joseon ambassadors did not communicate with the "enemy" through literature. Once peace between the two countries stabilized, exchanges with Japan increased. Premodern cultural exchange was a sharp reflection of the political situation at the time. Our researchers will introduce to you what they have discovered while focusing on the Samsa's actions to analyze various aspects of the Korea-Japan culture exchanges.

\section{Joseon Tongshinsa Literature}

Sahangroks Records

During the $17^{\text {th }}$ to $19^{\text {th }}$ century, after the Japanese Invasion of Korea, Korea and Japan had diplomatic exchange every 20 years from the $1^{\text {st }}$ exchange in 1607 , to the last and $12^{\text {th }}$ exchange in 1811. Each Tongshinsa delegation was a large envoy consisting of 400 500 people. However, only a few personnel 
that crossed over to Japan could write with Chinese characters. Some of these personnel wrote personal travel records known as Sahangrok. Because this was a period of national isolation, going overseas was a unique experience, and personal records such as Sahangrok were invaluable because they were a means by which the latest information regarding Japan were known to Joseon.

Our researchers have gathered a total of 47 Sahangroks that are distributed evenly amongst the 12 Tongshinsa delegations between 1607 and $1811^{1}$ Among the 47 Sahangroks, 8 were written by the highest ranking official, the Jeongsa, 7 were written by the $2^{\text {nd }}$ highest ranking official, the Busa, and 6 were written by the third highest ranking officer, the Jongsagwan. 21 of the 47 records were written by the Samsa, the three highest ranking officers. This implies that these officers showed great interest in the diplomatic delegations to Japan.

\section{Pildamchanghwaejib Records}

The Sahangrok records were kept in Joseon, while Japan kept the Pildamchanghwaejib records. Pildamchanghwaejib is a record of the various poetry and written communication and was published by the Japanese. The researchers were able to acquire 167 Pildamchanghwaejibs. ${ }^{2}$

As the Japanese became more familiar with the usage of Chinese characters, more Moonsas, the officials in charge of written communication, were sent in each delegation, and this lead to a great increase in the number of Pildamchanghwaejibs published after late 1700s. However, the presence of the Moonsas did not mean that the Samsa did not participate in poetic communication, written communication, and drawn communication with the Japanese. The Pildamchanghwaejibs show various records of the Samsa engaging in communication with Japanese in various ways. We will now analyze certain aspects of the exchange between the Samsa and the Japanese.

\section{Aspects of the Exchange between Joseon Samsa and the Japanese}

\section{Correspondence and Poetry}

Because the Tongshinsa delegation was only able to stay for a limited time, the number of Japanese they could meet was limited. Likewise, the number of Japanese that could interact with the delegation was also limited. The people of Tsushima were the middle party that provided the link between the Joseon Tongshinsa and the Japanese, and therefore, their permission was required before any exchange took place. As a result, direct confrontation was rare, and letters or correspondences were the main means of communication.

1. Cultural Heritage Administration of Korea, Study on Tongshinsa records review, translation and cataloging [통신사기록 조사, 번역 및/ 목록화 연구] (Daejeon: Cultural Heritage Administration of Korea, 2014), 7-9.

2. ibid., 10-18. 
In 1682, Tokugawa Mitsukuni (德川光國) was the lord of the Mitohan (水戶藩) providence and a scholar. He is known as the author of the first Japanese history record, "Great History of Japan (大日本史)", and showed great interest in history and the Joseon Tongshinsa delegations. When the Tongshinsa delegation was staying at Hinseiji (本誓寺) in Edo (江戸), it is recorded in The Record of Letters and Poetry Sent by Tokugawa Mitsukuni to the Joseon Delegation (水戶公朝鮮人贈答集).

The main content of the correspondence speaks of the 300 silver pieces (nyang) that Tokugawa Mitsukuni sent to the Samsa. The Samsa have never received such a gift from a Japanese party before, and were reluctant to receive the offering, while Tokugawa Mitsukuni hoped that they would receive his friendly gesture. Multiple letters were sent back and forth before the Samsa decided to accept the silver pieces, and Tokugawa Mitsukuni sent a prose to show his appreciation. The following is the poem that Tokugawa Mitsukuni sent to Jeongsa Yoon Ji-Wan in 1682.

$\begin{array}{ll}\text { 萬里勞來聘, } & \text { Thou have come a long way } \\ \text { 三韓尋舊盟 } & \text { Seeking the promises made in SamHan } \\ \text { 衣冠皆駭矚, } & \text { Clothes and headpiece astound the eyes } \\ \text { 草木亦知名 } & \text { The grass and trees also know thou name } \\ \text { 遽爾已臨別, } & \text { A sudden farewell brings } \\ \text { 黯然不盡情 } & \text { Sadness, prevents feelings from appearing } \\ \text { 㰾人若相問, } & \text { If they ask of Edo back home } \\ \text { 文物屬昇平 } & \text { Tell them all is Tranquil }\end{array}$

As can be seen in the last stanza of the poem, Tokugawa Mitsukuni wishes to show that "Japanese Civiliation is Peaceful" to the delegation. His gesture of the silver pieces may be seen as Japan's remorse for its past acts.

\section{Written Conversation}

In 1711, the Jeongsa Cho Tae-eok(趙泰億), the Busa Im Su-Gan(任守幹), and the Jongsagwan Yi Bang-Un (李邦彦), met Arayi Hakuseki (新井白石) in Edo and exchanged a number of written correspondences. Arayi Hakuseki was in charge of the welfare of the Tongshinsa delegation, and as he was the

3. Tokugawa Mitsukuni, The Recording of Letters and Poetry Sent by Tokugawa Mitsukuni to the Joseon Delegation [水戸公朝鮮人贈答集] (Edo, 1683). (Owned by The National Library of Korea). 
executive official of the Edo Shogunate, he was considered, to the delegation, to be the most influential person aside from the Shogun. Therefore, the written correspondence between the SamSa and Arayi Hakuseki can be considered as a series of written conversations between the respective countries' highest ranking ambassadors.

Their written conversation covered many areas, but the question and answer correspondence regarding the international politics of their surrounding countries is of special interest. Questions regarding China, pre-modern Asia's dominant country and questions about Ryukyu (琉球), which had exchanges with Joseon $14^{\text {th }}$ to $16^{\text {th }}$ century, came up frequently. For example, the written conversation below:

靑坪 ${ }^{4}$ : How far is Ryukyu (琉球) from here, and how far is it from Fujian (福建) and Nagasaki(長崎)?

白石 ${ }^{5}$ : Because $1 \mathrm{Li}$ in Japan is $10 \mathrm{Li}$ in Joseon, calculations show that it is $500 \mathrm{Li}$ from here. It is located in Nankai (南海), and since it is below the Sun's equator, it is known as Netskuni(熱國). The distance from Fujian (福建) and Nagasaki(長崎) should be the same.

南崗 $^{6}$ : I have heard that the number of merchant ships that go back and forth to China is limited, is this true?

白石 : I think the set number of DangSan ships that enter Nagasaki harbor is about 160 to $170 .^{7}$

For the two countries that emphasized a national seclusion policy at the time, the opportunity to investigate other countries affairs was an important one. Edo Japan's Nagasaki Harbor was where China's merchant ships entered Japan, and thus was an important topic for Joseon, which showed interest regarding the relationship between the two countries. For diplomatic groups such as the Tongshinsa delegation, where high ranking officials were part of the envoy, discrete investigation regarding the host countries current status could never be completely set aside. Consequently, the written conversations between the highest ranking ambassadors had an atmosphere of concern and tension to them. The ambassador had to make sure not to show too much information while saving face for the counterparts.

\footnotetext{
4. Pen name of Busa Im Su-Gan.

5. Ari Hakuseki.

6. Pen name of Jongsagwan Yi Bang-Un.

7. Im Su-Gan, "Conversations in the Edo and Writing in the Shimonoseki [江關筆談]", Dairy of Travel to East [東槎日記], 1711-12.
} 


\section{Drawing}

Several occasions where the Samsa left drawings have been discovered. Although the Tongshinsa delegation included officials, the Hwasung, who were in charge of drawn communication, sometimes the three Samsa was skilled at drawing and communicated with the Japanese through pictures. The Jongsa Cho Tae-eok, a Samsa who was part of the 1711 Tongshinsa envoy, was very skilled at drawing, and two of his drawings, "The painting of equestrian (騎馬圖)" ${ }^{8}$ and "The painting of Birds (渌毛圖)" ${ }^{9}$ were left in Japan. ${ }^{10}$ On the other hand, the Edo shogunate painter Kana Tsunenobu(狩野常信), drew a portrait of Cho Tae-eok, ${ }^{11}$ which can be found in the National Museum of Korea.

In 1764, when there was an increase in the activity between the Tongshinsa and Japan, physiognomists, including Niyama Daiho (新山退甫), analyzed dozens of Joseon people and recorded their findings in the Record of Conversations about Facial Features of Diplomats of Joseon(韓客人相箠話). ${ }^{12}$ The front portion of this book has the written correspondences that took place regarding physiognomy, and the latter half has pictures of Joseon peoples' faces. Although the Samsa of that delegation, the Jeongsa Cho Oem(趙曮), Busa Lee In-bae(李仁培), and Jongsagwan Kim sang-ik(金相翊), did not exchange any written correspondence with the physiognomists, their portraits are found in the book. In any case it can be inferred that the Japanese people showed interest in the Samsa.

\section{Letters}

Shizuokaken(靜岡縣) Seikenji (淸見寺) was visited by the Tongshinsa delegation 10 out of the 12 times an envoy was sent. This place houses the writings of various members of the Tongshinsa delegation, and some writings have been embellished with plaques and frames. ${ }^{13}$ Heungkuk (興國, which means prosperous country), written by the 1655 Jeongsa Cho Hyung, is placed

8. Owned by the Museum of Hallym University in Korea.

9. Unknown whereabouts. Mentioned by Nakamura Hidetaka, 趙泰億筆悀毛圖, 青丘学 叢Vol.4 (Osaka: 大阪屋号書店, 1931.)

10. Lee Won-sik, Study of Joseon Tongshinsa (Kyoto : 思文閣出版, 1997), 573-4.

11. Owned by National Museum of Korea.

12. Niyama Taiho, trans. Hur Kyoung-jin, Record of Conversations about Facial Features of Diplomats of Joseon [韓客人相筆話] (Seoul: 지식을 만드는 지식, 2009), 7-13.

13. Joseon Tongshinsa Cultural Society, Work Book of Pieces of Joseon Tongshinsa Owned by Seikenji [세이켄지 소장 조선통신사 유물도록] (Busan: Joseon Tongshinsa Cultural Society, 2006), 10-219. 
within a plaque before a Buddhist altar, and Dowon (桃原, which means field of peach), written by 1711 Jeongsa Cho Tae-eok, is engraved on a signboard within the Seikenji.

\section{Chan (贊)}

In premodern East Asia, Chan refers to any letters or words written above a drawing. The Joseon delegation made use of poetry, letters, and drawings to communicate with the Japanese. Sometimes members of the delegation would write above a drawing. The Samsa also communicated with the Japanese in this way.

\section{The Painting of Great Confucianist Saints (歷聖大儒像 $)^{14}$}

1636 Busa Kim Se-ryeom (金世濂) wrote this Chan on top of a drawing that was requested by Japanese confucianist Hayashi Razan (林羅山), to Kanoha artist Kano Sansetsu (狩野山雪). The drawing had 21 images of Confucianism saints and great scholars. In his anthology, it is written that Hayashi Razan asked Kim Se-ryeom, to add to his drawing because Kim Seryeom, was also a Confucianism scholar. Kim Se-ryeom's Chan includes elements from Confucius (孔子), Yan Hui(顔子), Zengzi(曾子), Mencius(孟子) and Kongji(子思).

2. The painting of Confucius (孔子圖) ${ }^{15}$

The original drawing was drawn by Kanoha artist Kano Naonobu (狩野尙信), and the Chan was added by the 1643 Jeongsa Yoon Soon-ji. The drawing is like its title, a drawing of Confucius. Yoon Soon-ji's Chan is the following:

Because thou have acknowledged Confucianism after studying it for a long time, it is not impossible for such a drawing to exist. (百世之後, 聞風而化, 繪亭之留於是邦, 固無不可.)

Confucius was to confucianists, the greatest saint. The Chan above states that because Japan has also embraced Confucianism, it is only proper that such a picture exists. The presence of the Chan, requested by the Japanese themselves, above the Japanese drawings "The Painting of Great Confucianist

14. Owned by the National Museum of Tokyo.

15. Private collection of Okada Taichi [岡田太-]. 
Saints (歷聖大儒像)" and "The Painting of Confucius (孔子圖)" indicate that Japan wished to communicate with Joseon Confucianism scholars. The Samsa obliged these wishes and wrote Chans above the drawings.

\section{Conclusion}

The Joseon Tongshinsa played a pivotal role as the bridge between the two countries. Although the main purpose of the envoy for Japan to send national correspondences and congratulate the ascension of a Shogun, this was also an opportunity for the two countries to have direct cultural exchange. Because both Joseon and Japan adamantly had National Seclusion policies in their governments, this small window of cultural exchange was deemed very important.

Additionally, although there were officials for different methods of communication, the three highest ranking officials, the Samsa, actively participated in the exchanges. This direct participation was made possible by the fact that these ambassadors were academics skilled in poetry, literature, and drawing. As a result, the Samsa used various methods to communicate with their Japanese counterparts.

Diplomatic relations between Korea and Japan were a combination of politics, culture, and literature. This paper is an analysis of the various exchanges, much different from contemporary political exchanges, through the recordings of the highest ranking officials, the Samsa.

\section{Bibliography}

Cultural Heritage Administration of Korea, Study on Tongshinsa records review, translation and catalogings [통신사기록 조사, 번역 및 목록화 연구],. Daejeon: Cultural Heritage Administration of Korea, 2014.

Joseon Tongshinsa. Cultural Society, Work Book of Pieces of Joseon Tongshinsa Owned by Seikenji [세이켄지 소장 조선통신사 유물도록]. Busan: Joseon Tongshinsa Cultural Society, 2006.

Im Su-Gan. "Conversations in the Edo and Writing in the Shimonoseki" ["江關筆談].

Dairy of Travel to East [東槎日記], 1711-12.

Lee Won-sik. Study of Joseon Tongshinsa. Kyoto: 思文閣出版, 1997.

Niyama Taiho. Translated by Hur Kyoung-jin, in Record of Conversations about Facial Features of Diplomats of Joseon [韓客人相筆話]. Seoul: 지식을 만드는 지식, 2009.

Tokugawa Mitsukuni. The Recording of Letters and Poetry Sent by Tokugawa Mitsukuni to the Joseon Delegation [水戶公朝鮮人贈答集]. Edo, 1683. 